\title{
A phosphorylation code for oestrogen receptor- $\alpha$ predicts clinical outcome to endocrine therapy in breast cancer
}

\author{
Georgios P Skliris, 1,2 , Zoann J Nugent ${ }^{2}$, Brian G Rowan ${ }^{3}$, Carla R Penner ${ }^{4}$, \\ Peter H Watson ${ }^{2,4,5}$ and Leigh C Murphy ${ }^{1,2}$
}

\author{
${ }^{1}$ Department of Biochemistry and Medical Genetics, Faculty of Medicine and ${ }^{2}$ Manitoba Institute of Cell Biology, University of \\ Manitoba, 675 McDermot Avenue, Winnipeg, Manitoba, Canada R3E 0V9 \\ ${ }^{3}$ Department of Structural and Cellular Biology, Tulane University School of Medicine and the Louisiana Cancer Research \\ Consortium, New Orleans, Louisiana 70112 USA \\ ${ }^{4}$ Manitoba Breast Tumour Bank, 675 McDermot Avenue, Winnipeg, Manitoba, Canada R3E 0V9 \\ ${ }^{5}$ Tumour Tissue Repository and Deeley Research Centre, BC Cancer Agency, Victoria, British Columbia, Canada V8B 6V5 \\ (Correspondence should be addressed to L C Murphy at Department of Biochemistry and Medical Genetics, Faculty of Medicine, \\ University of Manitoba; Email: Icmurph@cc.umanitoba.ca)
}

\begin{abstract}
To determine the relationship of the multiple sites of oestrogen receptor $\alpha(E R \alpha)$ phosphorylation to clinical outcome after tamoxifen therapy, sections from tissue microarrays representing over $300 \mathrm{ER}+$ breast cancers from patients who were treated with surgery + radiation and then tamoxifen were used for immunohistochemical determination of total $E R \alpha, p-S 104 / 106-E R \alpha$, $\mathrm{p}-\mathrm{S} 118-\mathrm{ER} \alpha, \mathrm{p}-\mathrm{S} 167-\mathrm{ER} \alpha, \mathrm{p}-\mathrm{S} 282-\mathrm{ER} \alpha, \mathrm{p}-\mathrm{S} 294-\mathrm{ER} \alpha, \mathrm{p}-\mathrm{T} 311-\mathrm{ER} \alpha$ and $\mathrm{p}-\mathrm{S} 559-\mathrm{ER} \alpha$. Relationships of phosphorylated ER $\alpha$ to overall and relapse-free survival (RFS; breast cancer death or recurrence) were tested using single (univariate) and multiple (multivariate) predictor statistical models. Large tumour size, node positivity, high grade, progesterone receptor (PR) negative status and low levels of $p-S 282-E R \alpha$ were significantly associated with reduced overall survival (OS). Along with tumour size and node status, a novel phosphorylation score $\left(P^{7}\right.$ score $\geq 3$ ), taking into account all seven $\mathrm{p}$-ER $\alpha$ sites, was significantly associated with reduced OS in univariate and multivariate analyses (hazard ratio $(\mathrm{HR})=2.24,95 \%$ confidence interval $(\mathrm{Cl})$ 1.15-4.34, $n=335 ; P=0.018$ ). Along with tumour size, node status, grade and PR status, a high $\mathrm{P}^{7}$ score $(\geq 3)$ was significantly associated with reduced RFS in univariate and multivariate analyses $(\mathrm{HR}=1.71,95 \% \mathrm{Cl} 1.03-2.86, n=332 ; P=0.039)$. Since $\mathrm{ER} \alpha$ is the site at which integration of diverse signals occurs to regulate breast cancer growth and survival, the ER $\alpha$ phosphorylation score may be a surrogate marker of the balance between oestrogen-dependent and crosstalk-dependent receptor activity, and is potentially a prognostic marker of clinical outcome in a tamoxifen-treated population of patients.
\end{abstract}

Endocrine-Related Cancer (2010) 17 589-597

\section{Introduction}

Oestrogen receptor $(E R \alpha)$ status of breast tumours is an imperfect marker of endocrine therapy response (Osborne 1998a,b), and there is a need for more precise biomarkers of treatment response.

$\mathrm{ER} \alpha$ is regulated by post-translational modifications such as phosphorylation. Phosphorylation of ER $\alpha$ at serine $(\mathrm{S})$, threonine $(\mathrm{T})$ and tyrosine $(\mathrm{Y})$ residues has been described previously (Lannigan 2003, Weigel \& Moore 2007a,b). In laboratory models, ER $\alpha$ ligand independence and resistance to tamoxifen antagonism can occur in part due to $\mathrm{ER} \alpha$ phosphorylation by kinases activated by growth factor receptor overexpression (Schiff et al. 2004). However, little is known of the relevance in vivo of phosphorylated ER $\alpha$ in breast cancer.

We were the first to show that detection of phosphorylation at serine $118(\mathrm{p}-\mathrm{S} 118)$ on $\mathrm{ER} \alpha$ in breast tumours is a feature of an intact oestrogendependent signalling pathway in vivo, and is associated 
with a better clinical outcome in patients treated with tamoxifen (Murphy et al. 2004a,b). Others have found similar results for phosphorylation at serine 167 (p-S167) on ER $\alpha$ (Yamashita et al. 2005, Jiang et al. 2007). Phosphorylation at these two sites in human breast tumours is generally associated with less aggressive tumour characteristics, suggestive of an intact oestrogen-responsive pathway. Furthermore, there is no difference in expression of p-S118-ER $\alpha$ and/or $\mathrm{p}-\mathrm{S} 167-\mathrm{ER} \alpha$ in $\mathrm{ER}+$ breast tumours that are HER 2-positive versus those that are HER 2-negative (Weitsman et al. 2006, Jiang et al. 2007, Murphy et al. 2009). These observations are in contrast to predictions from laboratory models, suggesting that these two sites of phosphorylation are associated with tamoxifen resistance (Campbell et al. 2001, Jordan 2004).

However, ER $\alpha$ can be phosphorylated at multiple sites (Lannigan 2003), and additional novel sites were recently identified (Al-Dhaheri \& Rowan 2006, Williams et al. 2007). Previously, we validated several phospho-specific antibodies for immunohistochemistry (IHC) on formalin-fixed paraffin-embedded (FFPE) breast tissue microarray (TMA) sections (Skliris et al. 2009). We now report that ER $\alpha$ phosphorylation sites are differentially associated with clinical outcome in a tamoxifen-treated population of patients.

\section{Methods}

\section{Tissue microarrays}

All primary invasive breast cancers used in this study were obtained from the Manitoba Breast Tumour Bank (MBTB, CancerCare Manitoba and University of Manitoba, www.umanitoba.ca/institutes/manitoba institute_cell_biology/MBTB/Index4.htm; Watson et al. 1996, Snell \& Watson 2006). MBTB embraces the policies and operating protocols of the Canadian Tumour Repository Network (www.CTRNet.ca), and operates with approval from the Research Ethics Board of the Faculty of Medicine, University of Manitoba.

The cases used in this study were selected from over 5000 cases accrued prospectively to the MBTB over the period 1988 to the present. All biospecimens represent tumour tissues submitted through standardized clinical protocols from several hospitals to a provincial steroid receptor laboratory attached to the MBTB collection. The majority of biospecimens originated from two tertiary care centres, but the site of origin was not a factor in subsequent case selection for this study. In this period, all tissues originated from surgical resections at all centres. All tissues were initially submitted as frozen tissue, and then a portion was converted into FFPE blocks. The composition and histopathology of all biospecimens in the MBTB are routinely assessed by a standardized protocol, and entered into a computerized database to enable selection based on tissue composition and clinicalpathological parameters (Skliris et al. 2006, 2009). Cases for this study were therefore able to be selected using inclusion criteria of ER positivity (ligandbinding assays (LBA) $>3 \mathrm{fmol} / \mathrm{mg}$ protein) and known treatment (surgery, with or without radiation), which included adjuvant tamoxifen therapy, and invasive ductal or lobular histology. Potential cases were re-reviewed on haematoxylin and eosin sections by pathologists ( $\mathrm{C} \mathrm{P}$ and $\mathrm{P} \mathrm{H} \mathrm{W}$ ) to confirm block composition and sufficient material in paraffin blocks to select areas for TMA coring. Duplicate $0.6 \mathrm{~mm}$ cores for each case were arrayed. By virtue of the nature of the biospecimens accrued to the MBTB, the regions cored for TMA typically corresponded to central tumour regions. Tissue collection and selection of samples for constructing TMAs have been reported before (Skliris et al. 2006, 2009, Snell \& Watson 2006, Barnes et al. 2008).

Overall, 450 cases were represented on the original TMAs, which were constructed prior to this study. However, due to exhaustion of tumour cores from previous use of the TMAs or incomplete data for some cases, the tumour numbers $(n)$ analysed for some markers were $<450$ (as indicated in the Results section).

Clinical-pathological characteristics of the final study cohort were as follows: PR-positive ( $>20 \mathrm{fmol} / \mathrm{mg}$ protein), 62\% (261/421); PR-negative, $38 \%$ (160/421); low-grade, $28 \%$ (118/420); intermediate-grade, $62 \%$ (260/420); high-grade, 10\% (42/420); tumour size $<2.5 \mathrm{~cm}, 56 \%$ (237/422); tumour size $>2.5 \mathrm{~cm}, 44 \%$ (185/422); age < 50 years, $7 \%(31 / 420)$; age $>50$ years, $93 \%$ (389/420); node-negative, $53 \%$ (219/415); node-positive, 47\% (196/415). The median follow-up was 99 months (range 9-217 months).

\section{Antibodies}

The antibodies used for IHC were validated previously (Al-Dhaheri \& Rowan 2006, Skliris et al. 2009): p-S104/106-ER $\alpha$, p-S282-ER $\alpha$, p-S294-ER $\alpha$, p-T311-ER $\alpha$ and $\mathrm{p}-\mathrm{S} 559-\mathrm{ER} \alpha$ were rabbit polyclonal affinitypurified antibodies $(1 \mathrm{mg} / \mathrm{ml}$, custom made by Bethyl Laboratories, Montgomery, TX, USA); p-S118-ER $\alpha$ (6J4, Cell Signaling, Danvers, MA, USA), p-S167-ER $\alpha$ (Abcam, Cambridge, MA, USA) and ER $\alpha$ (NCL-ER, clone 6F11, Novocastra Laboratories, Newcastle, UK) antibodies were used as previously described (Murphy et al. 2004b, Skliris et al. 2006). 


\section{Immunohistochemistry}

IHC for TMAs was performed as described previously (Skliris et al. 2006). Serial sections $(5 \mu \mathrm{m})$ were stained with anti-ER $\alpha$, anti-p-S104/106-ER $\alpha$, anti-p-S118-ER $\alpha$, anti-p-S167-ER $\alpha$, anti-p-S282-ER $\alpha$, anti-p-S294-ER $\alpha$, anti-p-T311-ER $\alpha$ and anti-p-S559-ER $\alpha$ as previously described (Skliris et al. 2009). Briefly, sections were submitted to antigen retrieval $(\mathrm{CC} 1$, Ventana Medical Systems, Tucson, AZ, USA) using an autoimmunostainer (Discovery Staining Module, Ventana Medical Systems).

\section{Quantification and cut-off selection}

Slides were scored using standard light microscopy. IHC scores derive from assessment of both staining intensity (scale $0-3$ ) and percentage of positive cells $(0-100 \%)$. These two scores were multiplied to generate an IHC or $H$ score of 0-300. Only nuclear staining was evaluated and scored. TMAs were evaluated independently by up to three investigators (G P S, C P and P H W). Where discordance was found, cases were re-evaluated to reach consensus. Since no relevant clinical cut-off points are presently reported for any phosphorylated $\mathrm{ER} \alpha$ sites, positivity reported in this study was solely based on IHC scores greater than the 25th percentile (Skliris et al. 2009).

Relapse-free survival (RFS) was defined as the time from initial surgery to the date of clinically documented local or distant disease recurrence or death attributed to breast cancer (censors were other death). Overall survival (OS) was defined as the time from initial surgery to the date of death attributable to breast cancer (censors were other death).

\section{Statistical methodology}

Statistical analyses of survival were performed using SAS (Cary, NC, USA) version 9.1 procedure PHREG based on the modelling proposed by Cox (1972) for proportional hazard ( $\mathrm{PH})$ analysis. Compliance to the PH assumption was tested using the method of Lin et al. (1993). Each model was tested and complied with the assumption of PH. Analyses were performed with single predictors and in a multivariant model with backward selection at $P=0.05$ critical value. Probabilities associated with single predictors were corrected for multiple comparisons with Bonferroni's correction: $p^{\prime}=1-(1-p)^{k}$, where $p$ is the probability and $k$ is the number of comparisons.

\section{Results}

Previously, we had validated antibodies for several known and novel phosphorylated sites on ER $\alpha$ for IHC of TMA sections of FFPE primary breast cancer cases stored in MBTB (Skliris et al. 2009). ER $\alpha$-positive status was confirmed by IHC as previously described (Skliris et al. 2009), and only tumours positive for ER $\alpha$ using clinically derived cut points for both LBA ( $>3 \mathrm{fmol} / \mathrm{mg}$ protein) and IHC ( $>0 H$ score) were included in the analysis of the relationship of multiple phospho-ER $\alpha$ epitopes with clinical outcome.

Single predictor (univariate) analysis is shown in Tables 1 and 2 for OS or RFS respectively. Since 13 predictors are present, both probability and Bonferronicorrected probabilities are presented for the single predictor models. Large tumour size, node positivity, high grade and PR-negative status (Fig. 1A and B) were all significantly associated with reduced OS

Table 1 Univariate analysis of factors associated with overall survival (death due to breast cancer)

\begin{tabular}{|c|c|c|c|c|c|}
\hline Predictor & $n$ & HR & $95 \% \mathrm{Cl}$ & $P$ & $\begin{array}{c}\text { Bonferroni's } \\
\text { correction }(k=13)\end{array}$ \\
\hline Age $\geq 50$ years & 420 & 1.67 & $0.74-3.81$ & 0.22 & 0.96 \\
\hline Size $>2.5 \mathrm{~cm}$ & 422 & 2.27 & $1.56-3.30$ & $<0.0001^{*}$ & $<0.0013^{*}$ \\
\hline Node + & 415 & 2.06 & $1.42-3.00$ & $0.0002^{*}$ & $0.0026^{*}$ \\
\hline Grade & 420 & 1.38 & $1.02-1.87$ & $0.035^{\star}$ & 0.37 \\
\hline $\mathrm{PR}(\mathrm{LBA})>20 \mathrm{fmol} / \mathrm{mg}$ & 421 & 0.61 & $0.42-0.87$ & $0.0068^{*}$ & 0.08 \\
\hline $\mathrm{pS} 104 / 6+$ & 300 & 0.87 & $0.57-1.33$ & 0.52 & $>0.99$ \\
\hline pS118+ & 370 & 0.74 & $0.50-1.10$ & 0.132 & 0.85 \\
\hline pS167+ & 399 & 0.95 & $0.65-1.38$ & 0.77 & $>0.99$ \\
\hline pS282+ & 409 & 0.62 & $0.42-0.91$ & $0.015^{\star}$ & 0.18 \\
\hline pS294+ & 409 & 0.95 & $0.65-1.39$ & 0.80 & $>0.99$ \\
\hline pT311+ & 409 & 1.67 & $1.00-2.81$ & 0.0510 & 0.50 \\
\hline pS559+ & 410 & 1.23 & $0.80-1.89$ & 0.34 & $>0.99$ \\
\hline Phospho ${ }^{7}$-score $3+$ & 340 & 2.78 & $1.45-5.35$ & $0.0022^{*}$ & $0.03^{*}$ \\
\hline
\end{tabular}

HR, hazard ratio. *Significant, $P<0.05$. 
Table 2 Univariate analysis of factors associated with recurrence-free survival (RFS)

\begin{tabular}{|c|c|c|c|c|c|}
\hline Predictor & $n$ & HR & $95 \% \mathrm{Cl}$ & $P$ & $\begin{array}{c}\text { Bonferroni's } \\
\text { correction }(k=13)\end{array}$ \\
\hline Age $\geq 50$ years & 420 & 1.57 & $0.80-3.07$ & 0.19 & 0.94 \\
\hline Size $>2.5 \mathrm{~cm}$ & 422 & 1.85 & $1.36-2.51$ & $<0.0001^{*}$ & $<0.0013^{*}$ \\
\hline Node + & 415 & 2.02 & $1.48-2.76$ & $<0.0001^{*}$ & $<0.0013^{\star}$ \\
\hline Grade & 420 & 1.45 & $1.12-1.88$ & $0.0055^{\star}$ & 0.07 \\
\hline $\mathrm{PR}(\mathrm{LBA})>20 \mathrm{fmol} / \mathrm{mg}$ & 421 & 0.60 & $0.44-0.81$ & $0.001^{*}$ & $0.013^{*}$ \\
\hline pS104/6+ & 300 & 0.901 & $0.63-1.30$ & 0.59 & $>0.99$ \\
\hline pS118+ & 370 & 0.69 & $0.50-0.96$ & $0.0283^{\star}$ & 0.31 \\
\hline pS167+ & 399 & 0.91 & $0.66-1.25$ & 0.55 & $>0.99$ \\
\hline pS282+ & 409 & 0.61 & $0.44-0.86$ & $0.0039^{*}$ & $0.0495^{\star}$ \\
\hline pS294+ & 409 & 0.86 & $0.63-1.18$ & 0.35 & $>0.99$ \\
\hline pT311+ & 409 & 1.57 & $1.04-2.37$ & $0.0302^{*}$ & 0.33 \\
\hline pS559+ & 410 & 1.11 & $0.78-1.57$ & 0.57 & $>0.99$ \\
\hline Phospho ${ }^{7}$-score 3+ & 340 & 2.23 & $1.37-3.61$ & $0.0012^{*}$ & $0.02^{*}$ \\
\hline
\end{tabular}

HR, hazard ratio. *Significant, $P<0.05$.

and reduced RFS. These are previously identified predictors of clinical outcome and provide evidence that our study cohort is comparable to others published, despite a bias for larger tumour size due to the nature of the MBTB collection (Watson et al. 1996, Barnes et al. 2008) and selection for ER + status.

The current data confirm our earlier findings using a smaller cohort (Murphy et al. 2004a,b) that $\mathrm{p}-\mathrm{S} 118-\mathrm{ER} \alpha$ detection is associated with significantly longer RFS (hazard ratio $(\mathrm{HR})=0.69, P=0.028$, $n=370$ ) but not OS in patients treated with tamoxifen $(\mathrm{HR}=0.74, P=0.14, n=370$; Fig. $1 \mathrm{~A}$ and $\mathrm{B})$. It should be noted that 51 of the cases present in our earlier study (Murphy et al. 2004a) were present on the TMAs used in the current study.

Our results show that high levels of phosphorylation at the previously unstudied site p-S282-ER $\alpha(>25 \%$ $H$ score) are significantly associated with both longer RFS (HR $=0.61, P=0.0039, n=409$; Fig. $1 \mathrm{~B})$ and OS $(\mathrm{HR}=0.62, P=0.015, n=409$; Fig. 1 A $)$ on tamoxifen. These data again support the idea that detection of $\mathrm{p}-\mathrm{ER} \alpha$ in primary breast tumours is a marker for a functional oestrogen-dependent $\mathrm{ER} \alpha$ signalling pathway, and thus associated with a better tamoxifen response because these tumours are more dependent on ER $\alpha$ signalling for growth.

In contrast, higher phosphorylation levels at T311-ER $\alpha(>25 \% H$ score $)$ are significantly associated with shorter RFS (HR $=1.57, P=0.03, n=409$; Fig. 1B) and borderline significant shorter OS (HR $=1.67, P=0.051, n=409$; Fig. 1A) on tamoxifen. In our hands, T311-ER $\alpha$ is the first phosphorylation site that is associated with a poor clinical outcome on tamoxifen. As well, it was noted that, although not significant, the HR for higher $\mathrm{p}$-S559-ER $\alpha$ levels for OS was 1.23 and for RFS was 1.11. This outcome pattern resembles that for $\mathrm{p}$-T311-ER $\alpha$. These data provide further support for the idea that detection of $\mathrm{p}-\mathrm{ER} \alpha$ in primary breast tumours is a biomarker for a functional oestrogen-dependent ER $\alpha$ signalling pathway that can further discriminate tamoxifen response.

These results, together with our previous data (Skliris et al. 2009) and those of others (Jiang et al. 2007, Yamashita et al. 2008) supporting the presence of multiple phosphorylated forms of ER $\alpha$ in any one ER + tumour biopsy, suggested to us that a phosphorylation code for ER $\alpha$ may exist, analogous to the 'histone code' that provides a measure of functionality of the protein over and above measurement of the total protein. Since multiple pathways can impact directly or indirectly on ER $\alpha$ to affect activity (e.g. liganddependent versus ligand-independent; agonist versus antagonist activity of tamoxifen), it is possible that a measure of the balance between 'good' and 'bad' phospho-epitopes on ER $\alpha$ might provide a more precise predictor of outcome to tamoxifen and possibly other endocrine therapies.

To address this hypothesis, a phospho-epitope ER $\alpha$ score was developed to reflect the functional balance with respect to clinical outcome of all sites measured. Scores were dichotomized using the 25 th percentile IHC score for each epitope as a cut point for positive ( $>25$ th percentile value of 1) or negative. In some cases (e.g. p-S104/6-ER $\alpha$, p-S118-ER $\alpha$, p-S167-ER $\alpha$ and $\mathrm{p}-\mathrm{S} 294-\mathrm{ER} \alpha$ ), the actual $25 \%$ IHC score was 0 . Since in our analysis above, p-S104/6-ER $\alpha$, p-S118-ER $\alpha, \quad p-S 167-E R \alpha, \quad p-S 282-E R \alpha$ and $\mathrm{p}-\mathrm{S} 294-\mathrm{ER} \alpha$ are associated with an $\mathrm{HR}<1$, they 
A

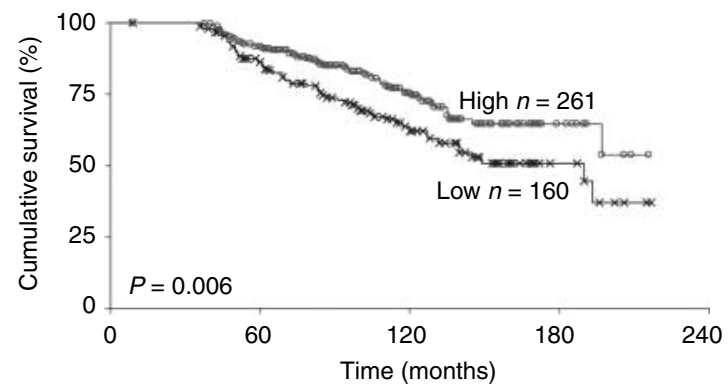

pT311 death from breast cancer

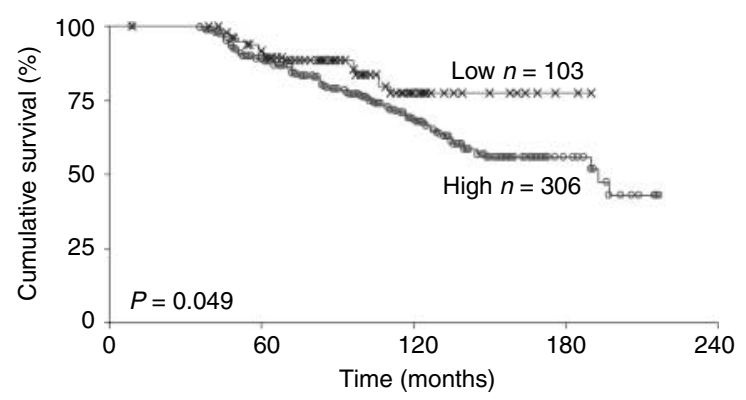

B
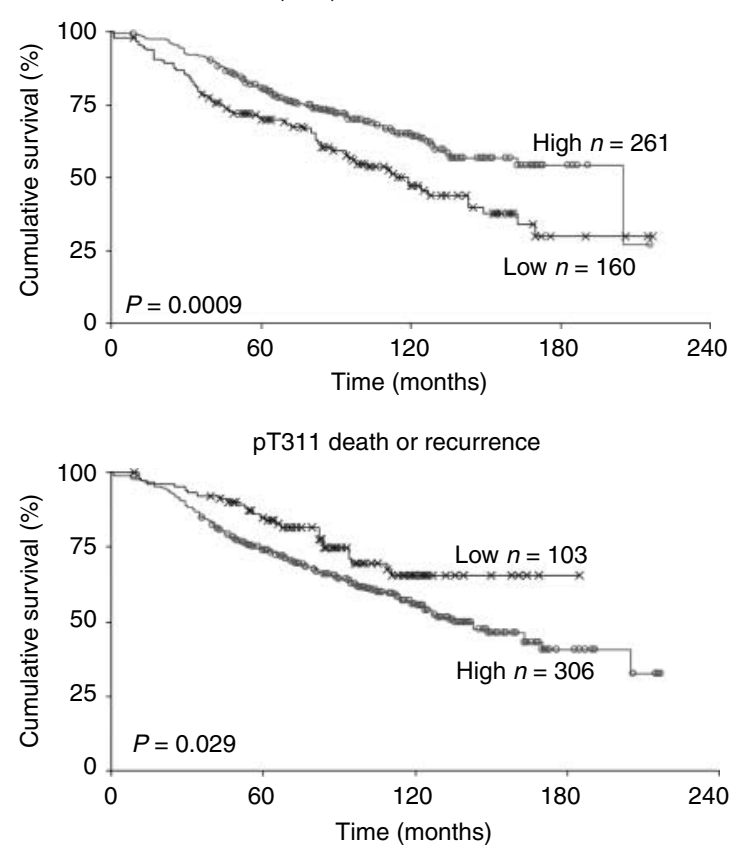

pS282 death from breast cancer
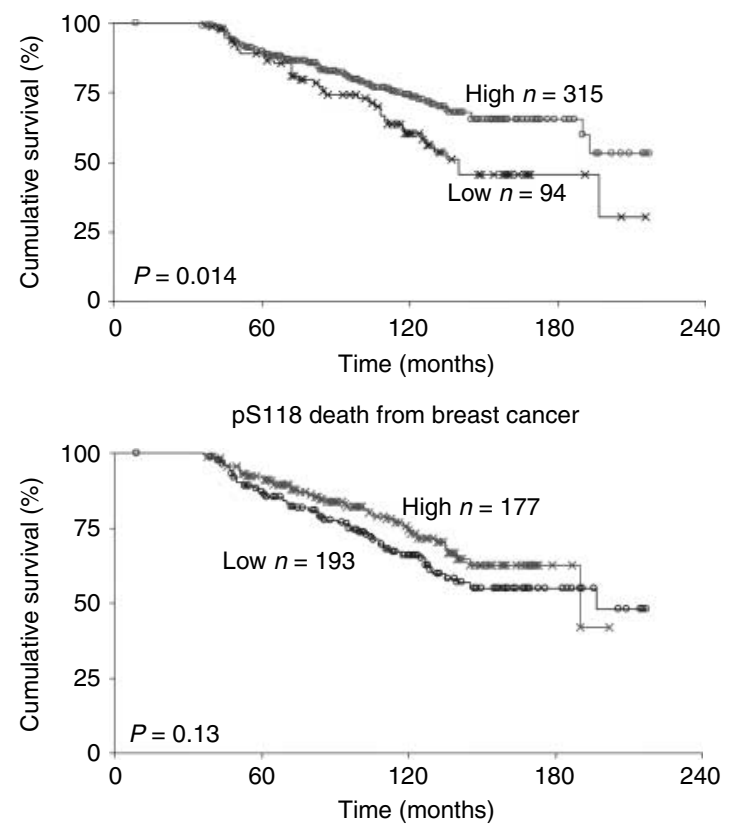

pS282 death or recurrence
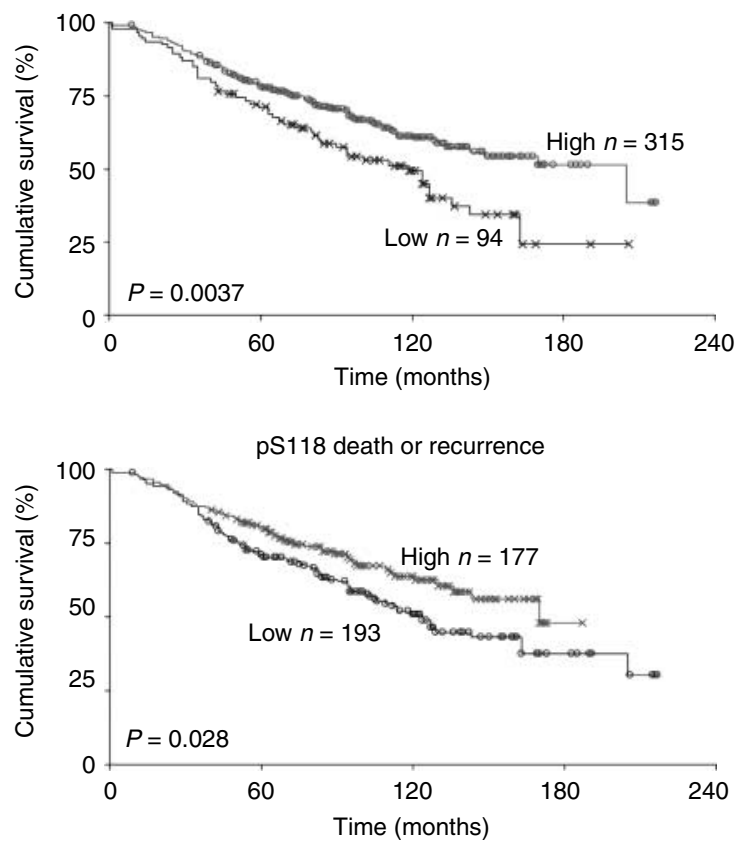

Figure 1 (A) Kaplan-Meier estimates of overall survival from breast cancer-specific death with respect to expression of PR (LBA, PR high $>20 \mathrm{fmol} / \mathrm{mg}$ protein (top left)); $\mathrm{p}-\mathrm{S} 282-\mathrm{ER} \alpha$ (high $>25 \% \mathrm{H}$ score, top right); $\mathrm{p}-\mathrm{T} 311$-ER $\alpha$ (high $>25 \% \mathrm{H}$ score, bottom left); p-S118-ER $\alpha$ (positive $>0 \mathrm{H}$ score, bottom right). (B) Kaplan-Meier estimates of relapse-free survival from breast cancer recurrence or breast cancer-specific death with respect to expression of PR (LBA, PR-positive $>20 \mathrm{fmol} / \mathrm{mg}$ protein (top left)); p-S282-ER $\alpha$ (top right); $p$-T311-ER $\alpha$ (bottom left); $p-S 118-E R \alpha$ (bottom right). $P$ value represents the significance of a simple survival analysis without the proportional hazard assumption that was applied in the analyses presented in Tables 1 and 2.

were considered as 'good' factors and given a negative value $(-1)$. Since $\mathrm{p}-\mathrm{T} 311-\mathrm{ER} \alpha$ and $\mathrm{p}-\mathrm{S} 559-\mathrm{ER} \alpha$ are associated with an HR above 1 , they are considered as 'bad' factors and given a positive value $(+1)$.
The sum of individual scores and a constant value $(v=$ number of epitopes tested -2$)$ was calculated to determine the $\mathrm{P}^{7}$-ER $\alpha$ score with the expectation that low $\mathrm{P}^{7}$-ER $\alpha$ scores would indicate better outcomes. 
For example, a tumour positive for $\mathrm{pS} 104 / 6-\mathrm{ER} \alpha$, p-S118-ER $\alpha, p-S 167-E R \alpha, p-S 282-E R \alpha$ and p-S294- ER $\alpha$, and positive for $\mathrm{p}-\mathrm{T} 311-\mathrm{ER} \alpha$ and $\mathrm{p}-\mathrm{S} 559-\mathrm{ER} \alpha$ would receive a $\mathrm{P}^{7}$-ER $\alpha$ score of $5-1-1-1-1-$ $1+1+1=2 ;$ a tumour positive for $\mathrm{p}-\mathrm{S} 118$-ER $\alpha$ and $\mathrm{p}-\mathrm{T} 311-\mathrm{ER} \alpha$ and negative for all the other sites would receive a score $=5-1+1=5$; and a tumour positive for $\mathrm{pS} 104 / 6-\mathrm{ER} \alpha, \mathrm{p}-\mathrm{S} 118-\mathrm{ER} \alpha, \mathrm{p}-\mathrm{S} 167-\mathrm{ER} \alpha$, $\mathrm{p}-\mathrm{S} 282-\mathrm{ER} \alpha$ and $\mathrm{p}-\mathrm{S} 294-\mathrm{ER} \alpha$ would receive a score $=5-1-1-1-1-1=0$.

Several cases were missing data for $\mathrm{p}-\mathrm{S} 104 / 6-\mathrm{ER} \alpha$. To maximize the data set, i.e. to increase the number of cases included in the analysis, these cases were included if data from the other sites were available. However, for these cases, the constant value used was 4 instead of 5 .

Using this approach, tumour phosphorylation scores of 3 or greater identified a population of patients with a significantly worse outcome on tamoxifen than those with scores below 3 (Fig. 2A for OS and Fig. 2B for RFS). In single predictor analysis, the HR was 2.78 for OS $(P=0.0022, n=340$; Table 1$)$ and 2.23 for RFS $(P=0.0012, n=340$; Table 2).
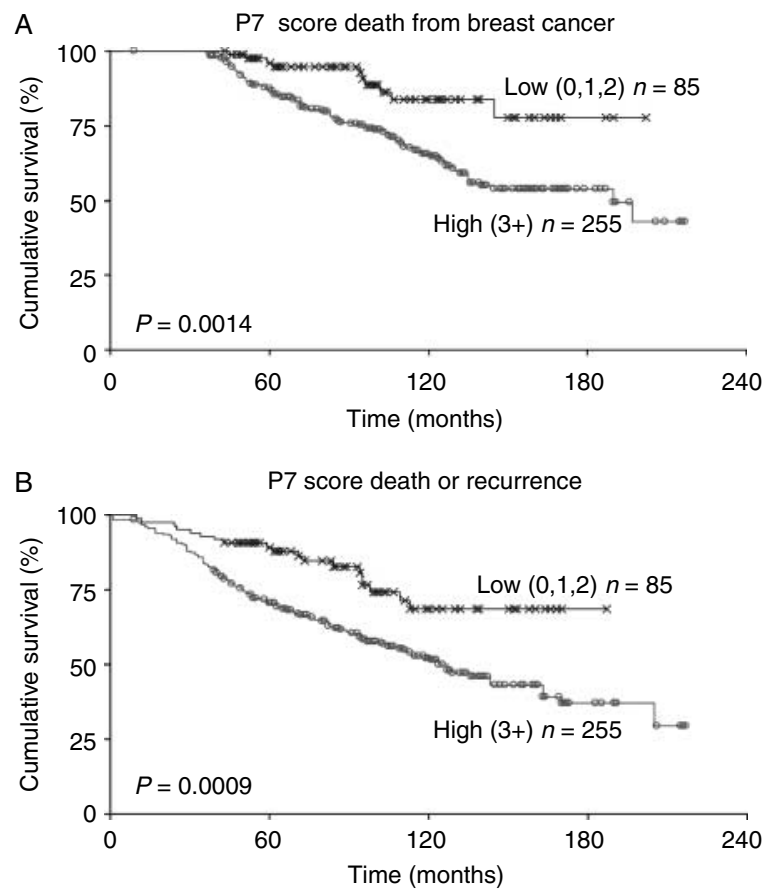

Figure 2 (A) Kaplan-Meier estimates of overall survival from breast cancer-specific death with respect to phosphorylation score $=\mathrm{P}^{7}$ score (high $\geq 3$ ). (B) Kaplan-Meier estimates of relapse-free survival from breast cancer recurrence or breast cancer-specific death with respect to $\mathrm{P}^{7}$ score (high $\geq 3$ ).

$P$ value represents the significance of a simple survival analysis without the proportional hazard assumption that was applied in the analyses presented in Tables 1 and 2 .
Table 3 Multivariate analysis of factors associated with overall survival (death due to breast cancer)

\begin{tabular}{|c|c|c|c|c|}
\hline Predictor & $n$ & HR & $95 \% \mathrm{Cl}$ & $\boldsymbol{P}$ \\
\hline Age $\geq 50$ years & 254 & 1.19 & $0.42-3.40$ & 0.75 \\
\hline Size $>2.5 \mathrm{~cm}$ & 254 & 2.12 & $1.34-3.37$ & $0.0014^{\star}$ \\
\hline Node + & 254 & 1.55 & $0.94-2.56$ & 0.085 \\
\hline Grade & 254 & 1.33 & $0.94-1.90$ & 0.11 \\
\hline $\begin{array}{l}\text { PR (LBA) } \\
\quad>20 \mathrm{fmol} / \mathrm{mg}\end{array}$ & 254 & 0.68 & $0.43-1.08$ & 0.10 \\
\hline pS104/6+ & 254 & 1.11 & $0.65-1.91$ & 0.71 \\
\hline pS118+ & 254 & 0.95 & $0.57-1.59$ & 0.85 \\
\hline pS167+ & 254 & 1.18 & $0.72-1.92$ & 0.52 \\
\hline pS282+ & 254 & 0.80 & $0.72-1.92$ & 0.38 \\
\hline pS294+ & 254 & 1.26 & $0.76-2.09$ & 0.37 \\
\hline pT311+ & 254 & 0.67 & $0.33-1.33$ & 0.25 \\
\hline pS559+ & 254 & 1.61 & $0.87-2.99$ & 0.13 \\
\hline Phospho ${ }^{7}$-score 3+ & 254 & 2.98 & $1.12-7.95$ & $0.029^{*}$ \\
\hline \multicolumn{5}{|c|}{$\begin{array}{l}\text { Multivariate analysis (best predictor model) with backward } \\
\text { selection }\end{array}$} \\
\hline Size $>2.5 \mathrm{~cm}$ & 335 & 1.97 & $1.31-2.97$ & $0.0012^{*}$ \\
\hline Node + & 335 & 1.66 & $1.09-2.52$ & $0.0176^{\star}$ \\
\hline Phospho ${ }^{7}$-score $3+$ & 335 & 2.24 & $1.15-4.34$ & $0.0175^{\star}$ \\
\hline
\end{tabular}

HR, hazard ratio. *Significant, $P<0.05$.

When multivariate analysis was undertaken, size and the phosphorylation score remained significant for OS (Table 3), while size, grade, PR status and phosphorylation score remained significant for RFS (Table 4).

Table 4 Multivariate analysis of factors associated with recurrence-free survival (RFS)

\begin{tabular}{|c|c|c|c|c|}
\hline Predictor & $n$ & HR & $95 \% \mathrm{Cl}$ & $\boldsymbol{P}$ \\
\hline Age $\geq 50$ years & 254 & 1.07 & $0.46-2.49$ & 0.88 \\
\hline Size $>2.5 \mathrm{~cm}$ & 254 & 1.79 & $1.22-2.63$ & $0.0028^{*}$ \\
\hline Node + & 254 & 1.36 & $0.89-2.09$ & 0.15 \\
\hline Grade & 254 & 1.41 & $1.04-1.92$ & $0.029^{*}$ \\
\hline $\begin{array}{l}\text { PR (LBA) } \\
\quad>20 \mathrm{fmol} / \mathrm{mg}\end{array}$ & 254 & & $0.40-0.086$ & $0.0067^{\star}$ \\
\hline pS104/6+ & 254 & 1.24 & $0.78-1.97$ & 0.37 \\
\hline pS118+ & 254 & 1.00 & 0.6 & 0.98 \\
\hline & 254 & 1.21 & $0.8-1$ & 0.37 \\
\hline pS282+ & 254 & 0.78 & $0.51-$ & 0.26 \\
\hline pS294+ & 254 & 1.30 & $0.84-2$ & 0.24 \\
\hline pT311+ & 254 & 0.82 & $0.46-1.45$ & 0.49 \\
\hline pS559+ & 254 & 1.32 & $0.8-2.17$ & 0.27 \\
\hline Phospho ${ }^{7}$-score $3+$ & 254 & 2.28 & $1.08-4.81$ & $0.03^{*}$ \\
\hline \multicolumn{5}{|c|}{$\begin{array}{l}\text { Multivariate analysis (best predictor model) with backward } \\
\text { selection }\end{array}$} \\
\hline Size $>2.5 \mathrm{~cm}$ & 332 & 1.74 & $1.24-2.46$ & $0.0015^{\star}$ \\
\hline Node + & 332 & 1.63 & $1.15-2.32$ & $0.0065^{\star}$ \\
\hline Grade & 332 & 1.36 & $1.03-1.80$ & $0.0301^{*}$ \\
\hline $\begin{array}{l}\text { PR (LBA) } \\
>20 \mathrm{fmol} / \mathrm{m}\end{array}$ & 332 & 0.63 & $0.45-0.89$ & $0.0083^{*}$ \\
\hline Phospho $^{7}$-score $3+$ & 332 & 1.71 & $1.03-2.86$ & $0.0392^{*}$ \\
\hline
\end{tabular}

HR, hazard ratio. *Significant, $P<0.05$. 
In addition, a multipredictor (multivariate) analysis with backward selection was undertaken. The best predictors for OS were size, node status and phosphorylation score (Table 3 ). The HR for $\mathrm{P}^{7}$-ER $\alpha$ score was $2.24(P=0.018, n=335)$ for OS on tamoxifen. For RFS (Table 4), the best predictors were size, node status, grade, PR status and phosphorylation score. The HR for $\mathrm{P}^{7}$-ER $\alpha$ score was 1.71 $(P=0.039, n=332)$. With the exception of grade predicting RFS, all significant associations in the multivariant analysis were also significantly considered singly with Bonferroni's correction.

\section{Discussion}

Modulation of nuclear receptor phosphorylation is known to significantly affect receptor function (Weigel \& Moore 2007a,b). Importantly, phosphorylation was suggested to affect the responsiveness of steroid receptors such as ER to SERMs such as tamoxifen (Schiff et al. 2005, Cui et al. 2006). Alteration of cell-signalling pathways occurs during breast tumourigenesis and breast cancer progression, and involves modulation of kinase and phosphatase activities. This knowledge has led to the suggestion that changes in cell signalling that lead to altered ER phosphorylation may underlie, in part, the development of altered sensitivity to ligands and/or the development of resistance to endocrine therapies.

Recently, antibodies to phospho-specific epitopes on $\mathrm{ER} \alpha$ became available and were deployed for breast tumour analysis. Detection of p-S118-ER $\alpha$ and/or $\mathrm{p}-\mathrm{S} 167-\mathrm{ER} \alpha$ and assessment of their relationship to histopathological parameters and clinical outcome to endocrine therapies (Gee et al. 2005, Bergqvist et al. 2006, Sarwar et al. 2006, Jiang et al. 2007, Yamashita et al. 2008) suggested that phosphorylation, at least at these two sites, predicted for better tamoxifen responsiveness. Presumably, this was because these tumours were more dependent on E2/ER $\alpha$ for growth (Murphy et al. 2004a,b). However, in contrast to results for $\mathrm{p}-\mathrm{S} 118$-ER $\alpha$ and/or $\mathrm{p}-\mathrm{S} 167-\mathrm{ER} \alpha$, it was reported that detection of $\mathrm{p}-\mathrm{S} 305-\mathrm{ER} \alpha$ in breast tumours from pre-menopausal women receiving tamoxifen for 2 years was associated with no benefit (Holm et al. 2008). Furthermore, experimental studies supported a role for $\mathrm{p}$-S305-ER $\alpha$ in tamoxifen resistance (Michalides et al. 2004, Zwart et al. 2007), suggesting that not all types of $\mathrm{p}-\mathrm{ER} \alpha$ necessarily predict good outcome in patients treated with endocrine therapies. However, we were unable to examine $\mathrm{p}-\mathrm{S} 305-\mathrm{ER} \alpha$ in our study using the antibodies available to us.
When considering possible mechanisms of action, it is interesting that the phospho-epitopes predicting for good outcome are clustered in the $\mathrm{N}$-terminus of $\mathrm{ER} \alpha$. In contrast, those that predict poor outcome, i.e. $\mathrm{p}-\mathrm{S} 305-\mathrm{ER} \alpha$ and $\mathrm{p}-\mathrm{T} 311-\mathrm{ER} \alpha$, are clustered towards the C-terminus, in the hinge region overlapping the $\mathrm{N}$-terminus of the ligand-binding domain.

Yamashita et al. (2008) previously suggested that differential levels of $\mathrm{p}-\mathrm{S} 118-\mathrm{ER} \alpha$ and $\mathrm{p}-\mathrm{S} 167-\mathrm{ER} \alpha$ together provide a significant marker of outcome in patients treated either with no systemic therapy, endocrine therapy or with endocrine therapy plus chemotherapy. The results presented here, along with those previously published (Skliris et al. 2009), extend this approach significantly to measure seven different p-ER $\alpha$ isoforms in over $300 \mathrm{ER}+$ tumours. Results of this current larger study are generally consistent with our previous results using smaller cohorts (Murphy et al. 2004a).

However, three additional significant and novel observations have now been made. First, high levels of the novel p-S282-ER $\alpha$ predicted for better outcome (RFS and OS) in a tamoxifen-treated population of patients. Second, detection of high levels of p-T311-ER $\alpha$ predicted a poorer outcome in a tamoxifen-treated population of patients. Third, closer examination of HRs for individual phosphorylation sites measured in this study suggested that two groups of phospho-epitopes exist: one associated with a better outcome and the other associated with a poor outcome in a tamoxifen-treated population of patients, leading us to hypothesize an ER $\alpha$ phosphorylation code.

We suggest that this phosphorylation code may more precisely reflect the functional status of ER $\alpha$-regulated events in tumours and, therefore, may more precisely predict prognosis. Our results suggest that a low phospho-score (reflecting the balance of good over bad sites) is a statistically significant independent predictor of better OS and RFS in a tamoxifen-treated population of patients.

In laboratory models, in addition to oestrogen, several crosstalk signal transduction pathways can affect the phosphorylation state of ER $\alpha$. Furthermore, each phospho-site and different pathways that may regulate it directly, or through crosstalk, are likely to be dynamic and show differential kinetics. Since ER $\alpha$ is pivotal in breast cancer biology, we suggest that ER $\alpha$ is the site at which integration of diverse signals occurs to regulate breast cancer cell growth and survival.

Since high $\mathrm{p}-\mathrm{S} 118$-ER $\alpha$ in breast tumours was also reported to predict a better response to aromatase inhibitors (Generali et al. 2009), we speculate that our phosphorylation score may also predict prognosis 
and/or treatment response to aromatase inhibitors. However, this remains to be determined, preferably using tissue samples from randomized clinical trials of aromatase inhibitors (Goss et al. 2003). It is tempting to speculate that, since many of the same signal transduction pathways can affect phosphorylation of ER $\alpha$ coregulators (Wu et al. 2005), combining the ER $\alpha$ phosphorylation score with that of key coregulators in breast cancer would improve prognosis and/or treatment prediction even more. However, because all patients in the cohort studied were treated with tamoxifen, our study does not differentiate between the prognostic and/or predictive significance of the $\mathrm{P}^{7}$-ER $\alpha$ score. This would require analysis of the $\mathrm{P}^{7}$-ER $\alpha$ score in a population of patients treated by surgery alone. Therefore, further studies are required to address this issue.

The current drive to provide more precise ways to inform clinical decision making with respect to personalized treatment strategies is highlighted by the TAILORx breast cancer clinical trial (http://www. cancer.gov/clinicaltrials/digestpage/TAILORx). This trial is to test the usefulness of a gene expression profile (Oncotype Dx) score to predict outcome of patients receiving endocrine therapy with and without added chemotherapy.

The same paradigm could be proposed for the ER $\alpha$ phosphorylation score. The ER $\alpha$ protein is the 'workhorse' and pivotal to the biology of ER + breast cancer. Therefore, in women with early-stage ER+ breast cancer, where it is uncertain whether the patient will benefit from the addition of chemotherapy and radiation to standard endocrine therapy, the ER $\alpha$ phosphorylation score may help predict endocrine therapy response in the tumour.

\section{Declaration of interest}

We declare that there is no conflict of interest that could be perceived as prejudicing the impartiality of the research reported.

\section{Funding}

This work was supported by the Canadian Institutes of Health Research (CIHR, CIHR MOP-14742), the CancerCare Manitoba Foundation (CCMF) and the Canadian Breast Cancer Foundation (CBCF). This study was also supported by the Manitoba Breast Tumour Bank, a member of the Canadian Tumour Repository Network, and is funded in part by CCMF and CIHR. We would like to thank Dr Lorne Brandes for reading the manuscript and his helpful suggestions.

\section{References}

Al-Dhaheri M \& Rowan B 2006 Application of phosphorylation site-specific antibodies to measure nuclear receptor signaling: characterization of novel phosphoantibodies for estrogen receptor alpha. Nuclear Receptor Signaling 4 e007.

Barnes RO, Parisien M, Murphy LC \& Watson PH 2008 Influence of evolution in tumor biobanking on the interpretation of translational research. Cancer Epidemiology, Biomarkers \& Prevention 17 3344-3350.

Bergqvist J, Elmberger G, Ohd J, Linderholm B, Bjohle J, Hellborg H, Nordgren H, Borg A, Skoog L \& Bergh J 2006 Activated ERK1/2 and phosphorylated oestrogen receptor alpha are associated with improved breast cancer survival in women treated with tamoxifen. European Journal of Cancer 42 1104-1112.

Campbell R, Bhat-Nakshatri P, Patel N, Constantinidou D, Ali S \& Nakshatri H 2001 Phosphatidylinositol 3-kinase/AKT-mediated activation of estrogen receptor alpha: a new model for anti-estrogen resistance. Journal of Biological Chemistry 276 9817-9824.

Cox D 1972 Regression models and life tables. Journal of the Royal Statistical Society. Series B 20 187-220.

Cui Y, Parra I, Zhang M, Hilsenbeck SG, Tsimelzon A, Furukawa T, Horii A, Zhang ZY, Nicholson RI \& Fuqua SA 2006 Elevated expression of mitogen-activated protein kinase phosphatase 3 in breast tumors: a mechanism of tamoxifen resistance. Cancer Research 66 5950-5959.

Gee J, Robertson J, Gutteridge E, Ellis I, Pinder S, Rubini M \& Nicholson R 2005 Epidermal growth factor receptor/ HER2/insulin-like growth factor receptor signalling and oestrogen receptor activity in clinical breast cancer. Endocrine-Related Cancer 12 S99-S111.

Generali D, Buffa FM, Berruti A, Brizzi MP, Campo L, Bonardi S, Bersiga A, Allevi G, Milani M, Aguggini S et al. 2009 Phosphorylated ERalpha, HIF-1alpha, and MAPK signaling as predictors of primary endocrine treatment response and resistance in patients with breast cancer. Journal of Clinical Oncology 27 227-234.

Goss P, Ingle J, Martino S, Robert N, Muss H, Piccart M, Castiglione M, Tu D, Shepherd L, Pritchard K et al. 2003 A randomized trial of letrozole in postmenopausal women after five years of tamoxifen therapy for early-stage breast cancer. New England Journal of Medicine 349 1793-1802.

Holm C, Kok M, Michalides R, Fles R, Koornstra R, Wesseling J, Hauptmann M, Neefjes J, Peterse J, Stål O et al. 2008 Phosphorylation of the oestrogen receptor alpha at serine 305 and prediction of tamoxifen resistance in breast cancer. Journal of Pathology 217 372-379.

Jiang J, Sarwar N, Peston D, Kulinskaya E, Shousha S, Coombes R \& Ali S 2007 Phosphorylation of estrogen receptor-alpha at Ser167 is indicative of longer diseasefree and overall survival in breast cancer patients. Clinical Cancer Research 13 5769-5776. 
Jordan VC 2004 Selective estrogen receptor modulation: concept and consequences in cancer. Cancer Cell 5 207-213.

Lannigan D 2003 Estrogen receptor phosphorylation. Steroids 68 1-9.

Lin D, Wei L \& Ying Z 1993 Checking the Cox model with cumulative sums of martingale-based residuals. Biometrika 80 557-572.

Michalides R, Griekspoor A, Balkenende A, Verwoerd D, Janssen L, Jalink K, Floore A, Velds A, Veer LVT \& Neefjes J 2004 Tamoxifen resistance by a conformational arrest of the estrogen receptor alpha after PKA activation in breast cancer. Cancer Cell 5 597-605.

Murphy L, Niu Y, Snell L \& Watson P 2004a Phosphoserine-118 estrogen receptor-alpha expression in primary human breast tumors in vivo is associated with better disease outcome in women treated with tamoxifen. Clinical Cancer Research 10 5902-5906.

Murphy LC, Cherlet T, Adeyinka A, Niu Y, Snell L \& Watson P 2004b Phospho-serine-118 estrogen receptor-alpha detection in human breast tumors in vivo. Clinical Cancer Research 10 1354-1359.

Murphy LC, Skliris GP, Rowan BG, Al-Dhaheri M, Williams C, Penner C, Troup S, Begic S, Parisien M \& Watson PH 2009 The relevance of phosphorylated forms of estrogen receptor in human breast cancer in vivo. Journal of Steroid Biochemistry and Molecular Biology 114 90-95.

Osborne C 1998a Steroid hormone receptors in breast cancer management. Breast Cancer Research and Treatment $\mathbf{5 1}$ 227-238.

Osborne C $1998 b$ Tamoxifen in the treatment of breast cancer. New England Journal of Medicine 339 1609-1618.

Sarwar N, Kim J, Jiang J, Peston D, Sinnett H, Madden P, Gee J, Nicholson R, Lykkesfeldt A, Shousha S et al. 2006 Phosphorylation of ERalpha at serine 118 in primary breast cancer and in tamoxifen-resistant tumours is indicative of a complex role for ERalpha phosphorylation in breast cancer progression. Endocrine-Related Cancer 13 851-861.

Schiff R, Massarweh S, Shou J, Bharwani L, Mohsin S \& Osborne C 2004 Cross-talk between estrogen receptor and growth factor pathways as a molecular target for overcoming endocrine resistance. Clinical Cancer Research 10 331S-336S.

Schiff R, Massarwah S, Shou J, Bharwani L, Arpino G, Rimawi M \& Osborne C 2005 Advanced concepts in estrogen receptor biology and breast cancer endocrine resistance: implicated role of growth factor signaling and estrogen receptor coregulators. Cancer Chemotherapy and Pharmacology 56 s10-s20.

Skliris G, Leygue E, Curtis-Snell L, Watson P \& Murphy L 2006 Expression of oestrogen receptor-beta in oestrogen receptor-alpha negative human breast tumours. British Journal of Cancer 95 616-626.
Skliris GP, Rowan BG, Al-Dhaheri M, Williams C, Troup S, Begic S, Parisien M, Watson PH \& Murphy LC 2009 Immunohistochemical validation of multiple phospho-specific epitopes for estrogen receptor alpha (ERalpha) in tissue microarrays of ERalpha positive human breast carcinomas. Breast Cancer Research and Treatment 118 443-453.

Snell L \& Watson P 2006 Breast tissue banking: collection, handling, storage, and release of tissue for breast cancer research. Methods in Molecular Medicine 120 3-24.

Watson P, Snell L \& Parisien M 1996 The NCIC-Manitoba Breast Tumor Bank: a resource for applied cancer research. Canadian Medical Association Journal 155 281-283.

Weigel N \& Moore N $2007 a$ Steroid receptor phosphorylation: a key modulator of multiple receptor functions. Molecular Endocrinology 21 2311-2319.

Weigel NL \& Moore NL 2007b Kinases and protein phosphorylation as regulators of steroid hormone action. Nuclear Receptor Signaling 5 e005.

Weitsman G, Li L, Skliris G, Davie J, Ung K, Curtis-Snell L, Tomes L, Watson P \& Murphy L 2006 Estrogen receptoralpha phosphorylated at serine 118 is present at the promoters of estrogen-regulated genes and is not altered due to Her2 over-expression. Cancer Research $\mathbf{6 6}$ 10162-10170.

Williams C, Smith CL \& Rowan BG 2007 Identification of four novel phosphorylation sites in estrogen receptor $\alpha$ : impact on receptor-dependent gene expression and phosphorylation by protein kinase $\mathrm{CK} 2$. In The Endocrine Society's 89th Annual Meeting, pp P2-P258. Toronto, Canada.

Wu C, Chang Y, Shih J \& Lee Y 2005 The significance of estrogen receptor beta in 301 surgically treated non-small cell lung cancers. Journal of Thoracic and Cardiovascular Surgery 130 979-986.

Yamashita H, Nishio M, Kobayashi S, Ando Y, Sugiura H, Zhang Z, Hamaguchi M, Mita K, Fujii Y \& Iwase H 2005 Phosphorylation of estrogen receptor alpha serine 167 is predictive of response to endocrine therapy and increases postrelapse survival in metastatic breast cancer. Breast Cancer Research 7 R753-R764.

Yamashita H, Nishio M, Toyama T, Sugiura H, Kondo N, Kobayashi S, Fuji Y \& Iwase H 2008 Low phosphorylation of estrogen receptor $\alpha(\mathrm{ER} \alpha)$ serine 118 and high phosphorylation of $\mathrm{ER} \alpha$ serine 167 improve survival in ER-positive breast cancer. Endocrine-Related Cancer 15 755-763.

Zwart W, Griekspoor A, Berno V, Lakeman K, Jalink K, Mancini M, Neefjes J \& Michalides R 2007 PKA-induced resistance to tamoxifen is associated with an altered orientation of ERalpha towards co-activator SRC-1. EMBO Journal 26 3534-3544. 